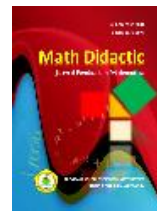

MATH DIDACTIC: JURNAL PENDIDIKAN MATEMATIKA

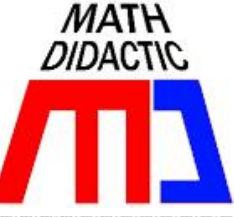

Tersedia Daring pada http://jurnal.stkipbjm.ac.id/index.php/math

\title{
KEEFEKTIFAN PEMBELAJARAN PROBLEM POSING TERHADAP PENINGKATAN PRESTASI DAN MINAT BELAJAR MAHASISWA
}

\author{
EFFECTIVENESS OF PROBLEM POSING \\ ON INCREASING ACHIEVEMENTS AND STUDENTS LEARNING INTERESTS
}

\author{
Erlyka Setyaningsih \\ Universitas Muhammadiyah Ponorogo \\ erlyka.setyaningsih@gmail.com
}

\begin{abstract}
Abstrak: Tujuan dilaksanakan penelitian adalah menjelaskan dan membandingkan keefektifan pembelajaran problem posing dengan pembelajaran konvensional dilihat dari prestasi dan minat belajar mahasiswa. Penelitian ini menggunakan jenis eksperimen semu. Populasi terdiri atas seluruh mahasiswa jurusan akuntansi angkatan 2017/2018 Universitas Muhammadiyah Ponorogo yang jumlahnya ada 4 kelas. Sampel yang terpilih secara acak adalah Kelas B dan kelas D. Pembelajaran konvensional dilaksanakan di Kelas B selaku kelas kontrol. Sedangkan, pembelajaran problem posing dilakasankan di kelas D sebagai kelas eksperimen. Tes dan angket digunakan dalam teknik pengumpulan data. Instrumen pengumpulan data menggunakan soal tes untuk mengukur prestasi. Sedangkan untuk mengukur minat belajar mahasiswa digunakan angket. Uji MANOVA, uji t satu sampel, dan uji t dua sampel independent adalah teknik analisis data yang digunakan dalam penelitian ini. Berdasarkan penelitian dapat disimpulkan bahwa pada signifikansi 5\%, pembelajaran problem posing dikatakan efektif ditinjau dari variabel prestasi belajar dan variabel minat belajar mahasiswa. Pembelajaran konvensional efektif dilihat dari variabel prestasi tetapi tidak efektif dilihat dari variabel minat belajar mahasiswa. Pembelajaran problem posing lebih efektif dibandingkan dengan pembelajaran konvensional ditinjau dari variabel prestasi dan variabel minat belajar mahasiswa.
\end{abstract}

Kata Kunci: problem posing, prestasi belajar, minat belajar

Abstract: The objective of this study was to describe and to compare the effectiveness of problem posing approach and conventional approach in terms of learning achievement and learning interest. The research design used quasi-experimental. The research population consist of all accounting student at Muhammadiyah Ponorogo University of the year 2017/2018 consisting of four classes. Student from class B and D were taken as sample. Class $B$ as the control class was taught using convensional learning, while class $D$ as the experiment class was taught using problem posing approach. The data collecting techniques were a test and non-test whereas the instrumens were used to collect the data consisted achievement test and interest questionnaire. The data were analyzed using MANOVA test, one sample t test, and two samples independent t test. The result of the study by using significance level 5\%, showed that the problem posing approach was effective in terms of learning achievement and learning interest. Conventional aproach was only effective in term of learning achievement. Problem posing approach was more excellent compared to conventional approach in terms of learning achievement and learning interest.

Keywords: problem posing, learning achievement, learning interest

Cara Sitasi: Setyaningsih, E. (2019). Keefektifan pembelajaran problem posing terhadap peningkatan prestasi dan minat belajar mahasiswa. Math Didactic: Jurnal Pendidikan Matematika, 5(1), $32-42$. https://doi.org/10.33654/math.v5i1.286

Submitted: January 23th, 2019

Revised: April 9th, 2019

Published: April 30th, 2019

Available Online Since: April 16th, 2019 
Statistika adalah salah satu cabang ilmu pengetahuan yang memiliki peran penting dan bermanfaat. Statistika dapat dimanfaatkan dan diaplikasikan dalam berbagai bidang. Mata kuliah statistika merupakan mata kuliah yang dimasukkan ke dalam kurikulum berbagai program studi. Statistika juga sudah dikenalkan sejak Sekolah Dasar hingga Perguruan Tinggi. Mata kuliah statistika akan sangat membantu mahasiswa dalam penulisan tugas akhir. Oleh karena itu mahasiswa diharapkan lebih tertarik dalam mengikuti mata kuliah statistika sehingga dapat memahami materi statistika. Pemahaman yang baik terhadap setiap materi statistika tentunya akan membantu mahasiswa untuk menyelesaikan berbagai persolan dalam statistika. Dengan demikian diharapkan prestasi mahasiswa pada mata kuliah statistika juga akan baik.

Faktor lain yang juga turut berpengaruh dalam pembelajaran statistika adalah minat belajar mahasiswa. Secara teoritis, semakin besar minat belajar mahasiswa maka semakin tinggi pula prestasi yang dapat diraih. Mahasiswa yang memiliki minat tinggi terhadap statistika akan dengan senang hati mengikuti proses perkuliahan dan menyelesaikan berbagai tugas yang diberikan. Sedangkan mahasiswa dengan minat belajar yang rendah biasanya prestasi yang diraih juga kurang baik.

Elliott (2000, hal. 349) menyatakan bahwa minat adalah karakter yang diekspresikan dengan hubungan antara seseorang dengan suatu obyek atau aktifitas tertentu. Minat juga dipandang mirip dan berhubungan dengan rasa ingin tahu seseorang terhadap objek-objek tertentu. Sejalan dengan pendapat tersebut, Nitko (2011, hal. 430) mengemukakan bahwa minat merupakan bentuk pilihan tertentu dari suatu kegiatan pada saat seseorang tidak sedang dalam keadaan tertekan. Dengan kata lain, minat merupakan pilihan yang dilakukan seseorang yang berasal dari keinginannya sendiri dan bukan berasal dari pengaruh pihak lain.

Setelah peneliti melakukan observasi, dapat disimpulkan bahwa minat mahasiswa dalam belajar statistika masih rendah. Mahasiswa terlihat kurang antusias, cenderung diam, dan kurang aktif selama proses perkuliahan berlangsung.

Berdasarkan masalah tersebut maka perlu dikembangkan pembelajaran yang dapat membantu mahasiswa untuk meningkatkan prestasi dan minat belajarnya. Dosen harus melakukan perubahan terkait pembelajaran yang selama ini dilaksanakan, misalnya dengan menyelenggarakan proses pembelajaran berbeda. Salah satu pembelajaran yang dapat digunakan adalah melaksanakan pembelajaran problem posing.

Pembelajaran problem posing adalah salah satu jenis pembelajaran yang mampu mengembangkan keterampilan mahasiswa dalam memahami materi statistika. Sehingga diharapkan mahasiswa akan mampu menyelesaikan berbagai masalah dalam statistika. Dengan menggunakan problem posing diharapkan dapat mendongkrak minat belajar mahasiswa karena pembelajaran ini lebih berorientasi pada mahasiswa.

Para ahli merekomendasikan penggunaan pendekatan problem posing dalam proses pembelajaran karena memiliki banyak manfaat bagi peserta didik. Problem posing adalah kegiatan pembelajaran yang terkait dengan pembentukan masalah dan perumusan ulang masalah yang ada (Silver, 1994, hal. 19). Pernyataan ini sejalan dengan pendapat yang menyebutkan bahwa problem posing merupakan pembelajaran yang fokus terhadap perumusan masalah (Haji, 2011, hal. 58). 
Terkait dengan pembuatan soal, Brown \& Walter (2005, hal. 12) menyatakan bahwa accepting dan challenging adalah dua hal penting dalam pengajuan soal matematika. Accepting terkait tentang kemampuan seorang peserta didik dalam memahami kondisi yang diberikan atau kondisi yang sulit ditentukan. Sedangkan challenging terkait tentang seberapa jauh peserta didik merasa tertantang terhadap situasi dan kondisi yang telah disediakan sehingga mereka mampu untuk mengajukan soal.

Pembelajaran problem posing memiliki banyak keunggulan. Keunggulan tersebut adalah dapat meningkatkan pengembangan kemampuan peserta didik, melibatkan peserta didik untuk fokus pada struktur dari masalah yang mendasar dan menggunakan berbagai sumber untuk mengonstruksi masalah baru; dan peserta didik akan menggunakan kemampuan berpikir ilmiah dalam kehidupan sehari-hari (English \& Halford, 1995, hal 304). Stoyanova mengidentifikasi tiga kategori dalam problem posing: (a) free situations, yaitu peserta didik bebas membentuk soal tanpa batasan (b) semistructured situations, yaitu peserta didik diberikan soal terbuka atau diminta untuk membuat yang mirip dengan soal yang telah diberikan, dan (c) structured problem posing situations, yaitu peserta didik mengajukan soal dengan merumuskan kembali soal yang telah diselesaikan atau membuat variasi pertanyaan berdasarkan soal yang diberikan (Christou, Mousoulides, Pittalis, Pitta-Pantazi, \& Sriraman, 2005, hal 150). Kategori problem posing menurut Silver adalah (a) presolution posing, yaitu penyusunan soal berdasarkan stimulus yang disajikan; (b) within-solution posing, yaitu perumusan kembali soal yang sedang diselesaikan; dan (c) postsolution posing, yaitu pembuatan soal baru dengan cara memodifikasi soal yang telah diselesaikan (Kılıç, 2017, hal. 773).

Pada penelitian ini digunakan langkahlangkah pembelajaran problem posing sebagai berikut:

a. Pemilihan titik awal

Mahasiswa diberikan permasalahan atau kondisi dengan bantuan gambar, model benda, game, teorema, alat peraga, soal, atau solusi soal.

b. Menggali informasi dari masalah atau situasi yang diberikan

Mahasiswa diminta untuk membuat daftar berdasarkan hal yang diketahui dari masalah atau situasi yang ada.

c. Membuat pertanyaan berdasarkan informasi yang diperoleh

Mahasiswa diminta untuk membuat pertanyaan atau soal berdasarkan informasi yang diperoleh pada langkah $b$.

d. Memprediksi solusi dari soal yang dibuat Mahasiswa diminta untuk menyelesaikan soal yang dibuat.

e. Mendiskusikan hasil penyusunan soal dan solusi dari soal tersebut

Dosen memfasilitasi diskusi kelas dalam membahas hasil pekerjaan mahasiswa.

Berdasarkan paparan di atas, pelaksanaan pembelajaran dengan pendekatan problem posing dinilai penting oleh peneliti dan akan berdampak positif terhadap minat dan prestasi mahasiswa. Sehingga akan diteliti keefektifan pembelajaran problem posing ditinjau dari aspek prestasi belajar dan minat belajar.

\section{Metode Penelitian}

Eksperimen semu (quasi-experiment) dipilih dan digunakan dalam penelitian ini. Peneliti tidak dapat memilih sampel penelitian secara acak. Peneliti menggunakan kelompok- 
kelompok yang sudah ada yaitu kelas-kelas yang sudah terbentuk untuk kegiatan pembelajaran. Pembelajaran adalah variabel bebas pada penelitian ini. Terdapat dua macam pembelajaran yang digunakan yaitu problem posing dan konvensional.

Populasi penelitian adalah seluruh mahasiswa akuntansi semester 2 tahun ajaran 2017/2018 yang terdiri atas 4 kelas. Berdasarkan rancangan penelitian akan diambil 2 kelas secara acak dari 5 kelas. Kedua kelas terpilih tersebut selanjutnya diambil secara random untuk dijadikan sebagai kelas eksperimen dan kelas kontrol. Selanjutnya pada kelas eksperimen akan diberikan treatmen berupa pembelajaran problem posing dan pada kelas kontrol diberikan treatmen dengan pembelajaran konvensional. Selanjutnya dilakukan pengundian untuk memilih sampel. Hasilnya diperoleh kelas D sebagai kelas problem posing dan kelas B sebagai kelas konvensional.

Terkait pengumpulan data pada penelitian ini digunakan tes tertulis untuk tes prestasi dan angket minat belajar. Sedangkan instrumen pengumpulan data terdiri atas soal prestasi belajar dan angket minat belajar berbentuk skala likert. Soal prestasi belajar terdiri atas 20 soal pilihan ganda dan angket minat belajar terdiri atas 30 pernyataan.

Pengujian hipotesis dibagi menjadi dua tahap yaitu pengujian hipotesis sebelum perlakuan dan pengujian hipotesis setelah perlakuan. Data yang digunakan adalah data pretest dan postest prestasi dan minat belajar. Pengujian menggunakan bantuan software SPSS 20.

\section{Hasil Penelitian dan Pembahasan}

\section{Hasil}

Data tes prestasi belajar pada kedua kelas yang dideskripsikan terdiri nilai pretes dan postes yang dirangkum dalam tabel berikut.

Tabel 1. Data Tes Prestasi Belajar

\begin{tabular}{ccccc}
\hline & \multicolumn{2}{c}{ Kelas Problem Posing } & \multicolumn{2}{c}{ Kelas Konvensional } \\
& Pretes & Postes & Pretes & Postes \\
\hline Mean & 34,55 & 82,12 & 34,83 & 73,97 \\
Standar deviasi & 8,60 & 13,23 & 8,71 & 14,72 \\
Hasil maksimum & 50 & 55 & 50 & 45 \\
Hasil minimun & 20 & 100 & 20 & 100 \\
\hline
\end{tabular}

Tabel 1 menjelaskan bahwa sebelum adanya treatmen, rata-rata skor prestasi dan standar deviasi baik di kelas problem posing maupun konvensional hampir sama. Setelah diberikan perlakuan, rata-rata nilai prestasi belajar baik di kedua kelompok kelas meningkat. Peningkatan rata-rata kelas problem posing sebesar 47,57 poin sedangkan pada kelas konvensional meningkat sebesar 39,14 poin. Jadi rata-rata pada kelas problem posing lebih meningkat daripada kelas konvensional.

Selanjutnya hasil tes prestasi akan dikonversi ke dalam beberapa kategori yang ditampilkan dalam tabel 2. 
Tabel 2. Distribusi Frekuensi dan Persentase Prestasi Belajar

\begin{tabular}{ccccccccc}
\hline \multirow{2}{*}{ Kategori } & \multicolumn{3}{c}{ Kelas Konvensional } & \multicolumn{3}{c}{ Kelas Problem Posing } \\
& \multicolumn{2}{c}{ Sebelum } & \multicolumn{2}{c}{ Sesudah } & \multicolumn{2}{c}{ Sebelum } & \multicolumn{2}{c}{ Sesudah } \\
& F & $\%$ & F & $\%$ & F & $\%$ & F & $\%$ \\
\hline Sangat Tinggi & 0 & 0 & 8 & 27,6 & 0 & 0 & 18 & 54,5 \\
Tinggi & 0 & 0 & 13 & 44,8 & 0 & 0 & 13 & 39,4 \\
Sedang & 6 & 20,7 & 8 & 27,6 & 6 & 18,2 & 2 & 6,1 \\
Rendah & 21 & 72,4 & 0 & 0 & 24 & 72,7 & 0 & 0 \\
Sangat Rendah & 2 & 6,9 & 0 & 0 & 3 & 9,1 & 0 & 0 \\
\hline
\end{tabular}

Berdasarkan tabel 2 dapat diambil kesimpulan bahwa tidak ada mahasiswa yang berada pada dua kategori teratas di kedua kelas sebelum diberikan treatment. Setelah adanya treatment tidak ada mahasiswa yang berada pada dua kelompok kategori terbawah. Sebagian besar mahasiswa pada kelas eksperimen berada pada kategori sangat tinggi yaitu sebesar 54,5\%. Sedangkan sebagian besar mahasiswa pada kelas kontrol masuk dalam kategori tinggi yaitu sebesar $44,8 \%$.

Hasil angket minat belajar mahasiswa terhadap statistik pada kedua kelas diringkas dalam tabel berikut.

Tabel 3. Data Hasil Angket Minat Belajar

\begin{tabular}{ccccc}
\hline & \multicolumn{2}{c}{ Kelas Problem Posing } & \multicolumn{2}{c}{ Kelas Konvensional } \\
& Pretes & Postes & Pretes & Postes \\
\hline Rata-Rata & 98,67 & 110,70 & 98,59 & 102,07 \\
Standar deviasi & 8,98 & 11,06 & 9,69 & 10,45 \\
Skor tertinggi & 113 & 132 & 118 & 124 \\
Skor terendah & 80 & 90 & 85 & 87 \\
\hline
\end{tabular}

Kesimpulan yang diambil berdasarkan tabel 3 adalah rata-rata skor pretes minat belajar mahasiswa pada kelas problem posing hampir sama dengan kelas konvensional. Sedangkan pada kelas problem posing, ratarata skor postes minat belajar yang diraih ternyata lebih tinggi 8,63 poin dibandingkan dengan kelas konvensional.

Data hasil angket minat selanjutnya akan dikonversi ke dalam beberapa kategori yang dituliskan dalam tabel 4 . 
Tabel 4. Distribusi Frekuensi dan Persentase Minat Belajar

\begin{tabular}{ccccccccc}
\hline \multirow{2}{*}{ Kategori } & \multicolumn{3}{c}{ Kelas Konvensional } & \multicolumn{3}{c}{ Kelas Problem Posing } \\
& \multicolumn{2}{c}{ Pretes } & \multicolumn{2}{c}{ Postes } & Pretes & Postes \\
& F & $\%$ & F & $\%$ & F & $\%$ & F & $\%$ \\
\hline Sangat Tinggi & 0 & 0 & 8 & 27,6 & 0 & 0 & 18 & 54,5 \\
Tinggi & 0 & 0 & 13 & 44,8 & 0 & 0 & 13 & 39,4 \\
Sedang & 6 & 20,7 & 8 & 27,6 & 6 & 18,2 & 2 & 6,1 \\
Rendah & 21 & 72,4 & 0 & 0 & 24 & 72,7 & 0 & 0 \\
Sangat Rendah & 2 & 6,9 & 0 & 0 & 3 & 9,1 & 0 & 0 \\
\hline
\end{tabular}

Tabel 4 menjelaskan bahwa tidak ada mahasiswa yang memenuhi kategori sangat tinggi di kedua kelas sebelum diberikan treatment. Setelah adanya treatment semua mahasiswa hanya masuk pada kategori sangat tinggi, tinggi, dan sedang. Mahasiswa pada kedua kelas sebagian besar berada pada kategori tinggi yaitu masing-masing sebesar $78,8 \%$ dan 79,3\%. Pada kelas eksperimen, mahasiswa yang memenuhi kategori sangat tinggi sebesar 18,2 \% sedangkan pada kelas kontrol sebesar 10,3\%.

Selanjutnya untuk menjawab rumusan masalah, pertama-tama akan dilakukan uji normalitas, dilanjutkan uji homogenitas, dan terakhir dilakukan uji beda rata-rata. Setelah itu akan dilakukan uji hipotesis. Selanjutnya agar dapat mengetahui bahwa data sampel diambil dari populasi yang memiliki distribusi normal maka dilakukan uji normalitas prestasi belajar dan minat belajar mahasiswa baik pretes maupun postes pada kedua kelas. Uji normalitas meliputi uji normalitas multivariat dan univariat. Berikut ini disajikan uji normalitas multivariat pada tabel 5 .

Tabel 5. Hasil Uji Normalitas Multivariat

\begin{tabular}{ccc} 
Kelas & $\boldsymbol{d}_{\boldsymbol{i}}^{2}$ Pretes & $\boldsymbol{d}_{\boldsymbol{i}}^{2}$ Postes \\
\hline Problem posing & $51,52 \%$ & $33,33 \%$ \\
Konvensional & $48,28 \%$ & $51,72 \%$ \\
\hline
\end{tabular}

Berdasarkan tabel 5 dapat disimpulkan bahwa data posttest untuk kelas problem posing tidak memenuhi asumsi normal multivariat. Namun pendapat Steven (2009, hal. 222) mengatakan apabila studi yang dilaksanakan memiliki variabel yang kurang dari 10 maka uji $\mathrm{F}$ yang dilakukan pada Manova bersifat "robust" terhadap asumsi ketidaknormalan, sehingga hasil pengujian tidak terpengaruh oleh pelanggaran asumsi normal multivariat.

Uji normalitas univariat dapat diketahui dari hasil signifikansi Kolmogorovsmirnov. Tabel berikut ini merangkum hasil uji yang telah dilakukan.. 
Tabel 6. Data Hasil Uji Normalitas Univariat

\begin{tabular}{cccccc}
\hline \multirow{2}{*}{ Variabel } & \multirow{2}{*}{ Kelas } & \multicolumn{2}{c}{ Pretes } & \multicolumn{2}{c}{ Postes } \\
& & Sig & Keterangan & Sig & Keterangan \\
\hline \multirow{2}{*}{ Prestasi } & Konvensional & 0,459 & Normal & 0,844 & Normal \\
& Problem posing & 0,750 & Normal & 0,617 & Normal \\
\multirow{2}{*}{ Minat } & Konvensional & 0,748 & Normal & 0,801 & Normal \\
& Problem posing & 0,675 & Normal & 0,543 & Normal \\
\hline
\end{tabular}

Berdasarkan Tabel 6 dapat diketahui bahwa tiap-tiap variable terikat pada kelas problem posing dan kelas konvensional mempunyai nilai signifikansi yang lebih besar dari 0,05 sehingga dapat dikatakan bahwa asumsi normalitas terpenuhi.

Sama halnya dengan uji normalitas, uji homogenitas juga terdiri atas uji homogenitas multivariat dan uji homogenitas univariat. Hasil uji homogenitas masing-masing variable pada kedua kelas dapat dilihat pada tabel 7 .
Tabel 7. Hasil Uji Homogenitas Multivariat

\begin{tabular}{ccc}
\hline & Pretes & Postes \\
\hline Box's M & 2,744 & 2,050 \\
F & 0,881 & 0,659 \\
Sig & 0,450 & 0,577 \\
\hline
\end{tabular}

Tabel 7 menunjukkan bahwa nilai signifikansi yang didapatkan lebih besar dari 0,05 . Dengan demikian dapat dikatakan bahwa pada taraf nyata 0,05 matriks kovarians untuk kedua kelas homogen baik pada data sebelum maupun sesudah perlakuan. Selanjutnya ringkasan uji homogenitas univariat dapat dilihat pada tabel 8 .

Tabel 8. Hasil Uji Homogenitas Multivariat

\begin{tabular}{cllllll}
\hline Variabel & Data & F & df1 & df2 & Signifikansi & Keterangan \\
\hline \multirow{2}{*}{ Prestasi } & Pretest & 1,378 & 1 & 60 & 0,245 & Homogen \\
& Postest & 0,742 & 1 & 60 & 0,392 & Homogen \\
\multirow{2}{*}{ Minat } & Pretest & 0,025 & 1 & 60 & 0,875 & Homogen \\
& Postest & 0,712 & 1 & 60 & 0,402 & Homogen \\
\hline
\end{tabular}

Tabel 8 menunjukkan bahwa nilai signifikansi untuk variable prestasi belajar dan minat belajar mahasiswa lebih dari 0,05. Dengan kata lain, varians kedua kelas homogen untuk variabel prestasi belajar dan minat.

Sesudah uji normalitas dan uji homogenitas dilakukan maka hasil uji keefektifan pembelajaran problem posing dan konvensional dilihat dari prestasi belajar dan minat belajar mahasiswa akan ditampilkan pada tabel 9 .
Tabel 9. Hasil Uji One Sample t-test Problem posing Konvensional

\begin{tabular}{ccccc} 
& $\mathrm{t}_{\mathrm{h}}$ & $\mathrm{t}_{\mathrm{t}_{i}}$ & $\mathrm{t}_{\mathrm{h}}$ & $\mathrm{t}_{\mathrm{t}_{i}}$ \\
\hline Prestasi & 7,43 & 1,694 & 3,29 & 1,701 \\
Minat & 2,961 & 1,694 & $-1,51$ & 1,701 \\
\hline \multicolumn{5}{c}{ Tabel 9 menunjukkan } \\
bahwa nilai $\mathrm{t}_{\mathrm{h}}$
\end{tabular}
baik variable prestasi dan minat pada kelas problem posing lebih besar dibandingkan nilai $t_{t_{i}} \quad$ sehingga disimpulkan $H_{u}$ ditolak. Jadi dapat dinyatakan bahwa pada nilai signifikansi 5\% pembelajaran problem posing efektif dilihat dari prestasi dan minat belajar 
mahasiswa. Tabel 9 juga menjelaskan bahwa nilai $t_{h}$ untuk variable prestasi lebih besar dibandingkan nilai $t_{t_{i}}$ sehingga $H_{v}$ ditolak. Dengan demikian dapat disimpulkan bahwa pada taraf signifikansi $5 \%$ pembelajaran konvensional efektif dilihat dari prestasi belajar. Namun pembelajaran konvensional tidak efektif apabila dilihat dari variabel minat belajar mahasiswa.

Selanjutnya akan diuji apakah ada perbedaan kondisi awal antara kedua kelas yang diberikan treatmen sebelum perlakuan dan akan diuji apakah ada perbedaan keefektifan menggunakan problem posing dan konvensional dilihat dari prestasi dan minat belajar mahasiswa. Hasil uji disajikan dalam tabel berikut.

Tabel 10. Hasil MANOVA Data Pretes dan Postes

\begin{tabular}{ccc}
\hline & F & Sig \\
\hline Pretes & 0,047 & 0,954 \\
Postes & 4,914 & 0,011 \\
\hline
\end{tabular}

Berdasarkan tabel 10 didapatkan informasi bahwa nilai signifikansi $\mathrm{F}$ pada data pretes lebih besar dari 0,05 sedangkan pada data postes lebih kecil dari 0,05. Oleh karena itu dapat ditarik kesimpulan bahwa pada tingkat signifikansi 5\% tidak ada perbedaan kemampuan awal antara kelas problem posing dan kelas konvensional sebelum perlakuan. Sedangkan setelah perlakuan, ada perbedaan antar kedua kelas tersebut. Dengan kata lain ditemukan adanya perbedaan keefektifan antara pembelajaran problem posing dengan konvensional.

Setelah disimpulkan ada perbedaan keefektifan antar kedua pendekatan pembelajaran tersebut, langkah selanjutnya adalah melakukan uji independent sample ttest yang bertujuan untuk mengetahui pembelajaran mana yang lebih efektif ditinjau dari kedua variabel prestasi dan minat. Hasil uji independent sample t-test disajikan dalam tabel 11 berikut ini.

Tabel 11. Hasil Uji Independent Sample t-test

\begin{tabular}{cccc}
\hline Variabel & Sig & $\mathbf{t}_{\mathbf{h}}$ & $\mathbf{t}_{\mathbf{t}_{\mathbf{i}}}$ \\
\hline $\begin{array}{c}\text { Prestasi } \\
\text { Belajar }\end{array}$ & 0,0125 & 2,297 & 2,0017 \\
$\begin{array}{c}\text { Minat } \\
\text { Belajar }\end{array}$ & 0,0015 & 3,145 & 2,0017 \\
\hline
\end{tabular}

Berdasarkan tabel 11 dapat diketahui bahwa ada perbedaan keefektifan antara kelas eksperimen dan kelas kontrol yang ditinjau dari prestasi dan minat belajar mahasiswa. Data pada tabel menunjukkan bahwa nilai $t$ hitung yang diperoleh untuk variable prestasi belajar adalah 2,297 dan variable minat belajar mahasiswa adalah 3,145. Kedua nilai t hitung yang didapatkan ternyata lebih besar dibandingkan $\mathrm{t}$ tabel sehingga Ho ditolak. Sehingga disimpulkan bahwa problem posing lebih efektif daripada konvensional ditinjau dari variabel prestasi dan minat belajar mahasiswa.

\section{Pembahasan}

Hasil pengujian hipotesis yang telah dilaksanakan memperlihatkan bahwa pembelajaran problem posing efektif ditinjau dari prestasi belajar mahasiswa akuntansi pada mata kuliah statistik. Hal ini sejalan dengan penelitian yang menyatakan bahwa problem posing efektif untuk meningkatkan prestasi belajar (Setyaningsih \& Widjajanti, 2015, hal. 36). Hasil penelitian lain juga menyimpulkan hasil yang sama. (Narendrati, 2017, hal. 76).

Salah satu tahapan atau langkah dalam pembelajaran problem posing yang diduga berpengaruh terhadap peningkatan prestasi belajar mahasiswa adalah tahap membuat soal/pengajuan soal. Hal ini juga disampaikan oleh English (1997, hal. 172) yang menyatakan bahwa ide-ide yang dimiliki peserta didik dalam mengajukan soal dapat meningkatkan 
performanya dalam mencari solusi permasalahan. Hal ini dapat meningkatkan prestasi belajar siswa. Pada pelaksanaan penelitian ini, mahasiswa diminta untuk membuat soal dan jawabannya, kemudian bertukar soal dengan siswa lain. Hal inilah yang melatih pemahaman mahasiswa terhadap materi yang dipelajarinya sehingga diduga dapat meningkatkan prestasi belajar.

Hasil uji hipotesis menyatakan bahwa pembelajaran dengan problem posing efektif ditinjau dari minat belajar mahasiswa. Hasil penelitian ini sesuai dengan hasil penelitian (Xia, Lü, \& Wang, 2008, hal. 161) yang menunjukkan bahwa problem posing memberikan efek yang signifikan untuk meningkatkan minat belajar. Penelitian lain juga menyimpulkan bahwa problem posing efektif untuk meningkatkan minat belajar (Narendrati, 2017, hal. 76).

Tahapan dalam pembelajaran problem posing yang diduga dapat menumbuhkan minat belajar mahasiswa adalah tahap pemilihan masalah atau titik awal. Kegiatan pembelajaran yang dilakukan menggunakan kelompok-kelompok kecil yang berjumlah tiga sampai empat siswa per kelompok sehingga siswa dapat berdiskusi dan semakin tertarik mengikuti pembelajaran. Hal tersebut sesuai dengan teori Mitchell (Woolfolk, 2009, hal. 384) yang mengungkapkan bahwa menggunakan kelompok dapat membangkitkan minat belajar.

Hasil uji $\mathrm{t}$ dua sampel independen menyatakan apabila ditinjau dari prestasi belajar dan minat belajar mahasiswa maka dapat disimpulkan pembelajaran dengan problem posing lebih unggul daripada pembelajaran konvensional. Pembahasannya adalah sebagai berikut.

Hasil pengujian hipotesis menunjukkan bahwa ditinjau dari prestasi belajar mahasiswa. pembelajaran problem posing lebih unggul dibandingkan pembelajaran konvensional. Hal ini didukung oleh penelitian yang dilakukan (Susanti, Sukestiyarno, \& Sugiharti, 2012, hal. 18), yang menyatakan bahwa peningkatan prestasi yang belajar menggunakan problem posing lebih baik dibandingkan yang belajar di kelas biasa (konvensional).

Berdasarkan hasil penelitian menunjukkan bahwa rata-rata prestasi belajar mahasiswa mengalami peningkatan di kedua kelas. Rata-rata prestasi belajar mahasiswa yang dicapai di kedua kelas lebih tinggi dari nilai minimal yang ditetapkan.

Hasil penelitian menunjukkan bahwa pembelajaran problem posing lebih efektif dibandingkan dengan konvensional ditinjau dari minat belajar mahasiswa. Pada pembelajaran problem posing, siswa dikelompokkan dengan 3 - 4 orang anggota. Pengelompokkan ini berpengaruh terhadap minat belajar mahasiswa. Dengan adanya kelompok maka setiap mahasiswa dituntut untuk aktif dalam kegiatan diskusi kelompok saat proses pembelajaran. Hal ini juga sesuai dengan teori Mitchell (Woolfolk, 2007, hal. 384) yang menyatakan bahwa minat dapat dibangkitkan dengan terlibat aktif pada suatu kegiatan. Hal inilah yang menyebabkan mahasiswa yang terlibat aktif dalam kelompok maka minat belajarnya juga meningkat.

\section{Simpulan dan Saran}

\section{Simpulan}

Menurut hasil uji hipotesis dan pembahasan hasil penelitian maka dapat disimpulkan bahwa pembelajaran statistika dengan problem posing efektif ditinjau dari prestasi dan minat belajar mahasiswa, 
sedangkan pembelajaran konvensional hanya efektif jika ditinjau dari prestasi belajar namun tidak efektif jika ditinjau dari minat belajar mahasiswa. Hasil penelitian juga menyatakan bahwa dilihat dari prestasi dan minat belajar mahasiswa, pembelajaran yang menggunakan problem posing lebih unggul dibandingkan dengan konvensional.

\section{Saran}

Dosen atau peneliti yang ingin meningkatkan prestasi belajar mahasiswa dapat menerapkan pembelajaran problem posing. Dosen diharapkan dapat menggunakan pembelajaran problem posing dalam pembelajaran secara berkesinambungan agar diperoleh hasil belajar yang maksimal. Peneliti lain dapat melaksanakan penelitian lebih lanjut dengan menggunakan pembelajaran problem posing namun mencakup aspek selain prestasi belajar dan minat belajar serta menggunakannya pada materi pembelajaran lain atau mata kuliah selain statistika.

\section{Daftar Pustaka}

Brown, S. I., \& Walter, M. I. (2005). The art of problem posing $\left(3^{\text {rd }} e d\right)$. Mahwah, NJ: Lawrence Erlbaum Associates.

Christou, C., Mousoulides, N., Pittalis, M., Pitta-Pantazi, D., \& Sriraman, B. (2005). An empirical taxonomy of problem posing processes. ZDM - International Journal on Mathematics Education, 37(3), 149-158.

Elliot, S. N., et al. (2000). Educational psychology: Effective teaching, effective learning. New York: The McGraw-Hill Companies.

English, L. D. (1997). Promoting A Problem Posing Classroom. Teaching Children
Mathematics, 4, 172-180.

English, L. D. \& Halford, G. S. (1995). Mathematics education: Models and processes. New Jersey, Mahwah: Lawrence Erlbaum Associatesm, Inc.

Haji, S. (2011). Pendekatan Problem Posing dalam Pembelajaran Matematika Di Sekolah Dasar. Jurnal Kependidikan Triadik, 14(1), 55-63.

Kılıç, Ç. (2017). A new problem-posing approach based on problem-solving strategy: Analyzing pre-service primary school teachers' performance. Kuram ve Uygulamada Egitim Bilimleri, 17(3), 771-789.

Narendrati, N. (2017). Komparasi pembelajaran statistika melalui pendekatan CTL dan problem posing ditinjau dari prestasi belajar dan minat belajar matematika. Jurnal Riset Pendidikan Matematika, 4(1), 67-77.

Nitko, A. J. \& Brookhart, S. M. (2011). Educational assesment of students. Upper Saddle River, New Jersey: Pearson Education.

Setyaningsih, E., \& Widjajanti, D. B. (2015). Keefektifan Pendekatan Problem Posing Ditinjau dari Prestasi Belajar, Kemampuan Koneksi Matematis, dan Disposisi Matematis. PYTHAGORAS: Jurnal Pendidikan Matematika, 10(1), 28-37.

Silver, E. A. (1994). On Mathematical Problem Posing. Educational Studies in Mathematics, 1(July 1994), 19-28.

Susanti, E. L., Sukestiyarno, Y. L., \& Sugiharti, E. (2012). Problem Posing Berbasis Pendidikan Karakter. Unnes Journal of Mathematic Education, 1(2252), 13-19. 
Woolfolk, A. (2007). Educational psychology. Boston: Pearson Education.

Xia, X., Lü, C., \& Wang, B. (2008). Research on Mathematics Instruction Experiment Based Problem Posing. Journal of Mathematics Education, 1(1), 153-163. 